\title{
Somatic expansion of the C9orf72 hexanucleotide repeat does not occur in ALS spinal cord tissues
}

Jay P. Ross, BSc, Claire S. Leblond, PhD, Hélène Catoire, PhD, Kathryn Volkening, PhD, Michael Strong, MD, FRCPC, FANN, FCAHS, Lorne Zinman, MD, MSc, FRCPC, Janice Robertson, PhD, Patrick A. Dion, PhD, and Guy A. Rouleau, MD PhD, FRCPC

Neurol Genet 2019;5:e317. doi:10.1212/NXG.0000000000000317

\section{Abstract}

\section{Objective}

To test for somatic C9orf72 hexanucleotide repeat expansion (HRE) and hexanucleotide repeat length instability in the spinal cord of amyotrophic lateral sclerosis (ALS) cases.

\section{Methods}

Whole and partial spinal cords of 19 ALS cases were dissected into transversal sections $(5 \mathrm{~mm}$ thick). The presence of C9orf 72 HRE was tested in each independent section using RepeatPrimed PCR and amplicon-size genotyping. Index measures for the testing of mosaicism were obtained through serial dilutions of genomic DNA from an individual carrying a germline C9orf72 HRE in the genomic DNA of an individual without a C9orf72 HRE.

\section{Results}

None of the sections examined supported the presence of a subpopulation of cells with a C9orf72 HRE. Moreover, the C9orf 72 hexanucleotide repeat lengths measured were identical across all the spinal cord sections of each individual patient.

\section{Conclusions}

We did not observe somatic instability of the C9orf 72 HRE in disease relevant tissues of ALS cases.

\author{
Correspondence \\ Dr. Rouleau \\ guy.rouleau@mcgill.ca
}




\section{Glossary}

ALS = amyotrophic lateral sclerosis; HRE = hexanucleotide repeat expansion; $\mathbf{R P P C R}=$ repeat-primed PCR.

Amyotrophic lateral sclerosis (ALS) is a neurodegenerative disease characterized by rapid and progressive loss of motor neurons. ${ }^{1}$ Although germline mutations in several genes have been identified, the C9orf72 hexanucleotide repeat expansion (HRE) is currently one of the most prevalent and penetrant cause of ALS. ${ }^{1}$ In the general population, C9orf72 contains less than 30 GGGGCC repeats in the first intron, whereas in ALS cases the number of repeats ranges between hundreds to thousands. ${ }^{1}$ Because it is difficult to precisely size the repeat length above $30,{ }^{2}$ many aspects of C9orf72-related ALS have not been thoroughly investigated.

Somatic mutations have been hypothesized as a possible cause of ALS in cases who do not have germline mutations in genes known to be associated with the disease. ${ }^{3}$ Repeat sequences are particularly of interest for somatic mutation analysis because their emergent secondary structures can lead to expansion or contraction of repeat lengths. ${ }^{4}$ It is also notable that the C9orf $72 \mathrm{HRE}$ can lead to cell-to-cell transmission of dipeptide repeat proteins, ${ }^{5}$ and as such, it is conceivable that a small population of $C 9$ orf $72 \mathrm{HRE}$ cells nested in the nervous system could potentiate ALS.

Recently, somatic recombination of APP has been demonstrated to occur in Alzheimer's disease neurons. ${ }^{6}$ Because somatic expansion of $C 9$ orf 72 hexanucleotide repeats is a potential mechanism for ALS pathogenesis and because routine blood DNA testing would not identify such somatic events, ${ }^{2}$ we tested DNA extracted from finely sectioned spinal cords of 19 patients with ALS for low levels of the C9orf72 HRE.

Table Description of the ALS patient cohort

\begin{tabular}{|c|c|c|c|c|c|}
\hline Individual & No. sections & Age & Sex & Site of onset & Germline mutations \\
\hline ALS01 & 108 & 50 & M & Left hand & None \\
\hline ALS02 & 75 & 69 & $\mathrm{~F}$ & Right hand & None \\
\hline ALS03 & 96 & 62 & $\mathrm{~F}$ & Bulbar & None \\
\hline ALS04 & 70 & 79 & M & Right leg & None \\
\hline ALS05 & 118 & 78 & M & Bulbar & NEK1 p.P318L \\
\hline ALS06 & 78 & 58 & $\mathrm{~F}$ & Right hand & None \\
\hline ALS07 & 78 & & & Left foot & None \\
\hline ALS08 & 88 & & & Left hand & None \\
\hline ALS09 & 82 & & & Right foot & None \\
\hline ALS10 & 22 & 66 & M & & None \\
\hline ALS11 & 28 & 62 & M & & None \\
\hline ALS12 & 30 & 61 & M & & TBK1 p.L306I, CCNF p.E396D, SPG11 p.R1992Q \\
\hline ALS13 & 17 & 57 & M & & None \\
\hline ALS14 & 38 & 66 & $\mathrm{~F}$ & & None \\
\hline ALS15 & 11 & 78 & $\mathrm{~F}$ & Bulbar & None \\
\hline ALS16 & 21 & 62 & M & & None \\
\hline ALS17 & 31 & 71 & M & & None \\
\hline ALS18 & 22 & 69 & $\mathrm{~F}$ & & None \\
\hline ALS19 & 31 & 67 & $\mathrm{~F}$ & & SPAST p.R221C \\
\hline
\end{tabular}

Abbreviation: ALS = amyotrophic lateral sclerosis.

Site of onset refers to the initial location of ALS symptoms, Sections refer to the number of $\sim 5 \mathrm{~mm}$ spinal cord samples generated from each spinal cord. A total of 1,053 unique sections were tested. 


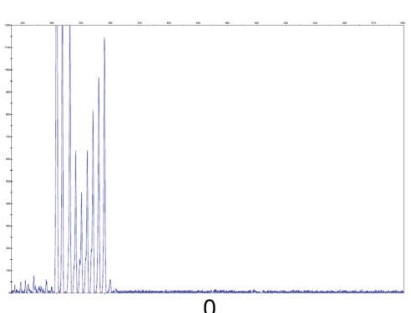

0

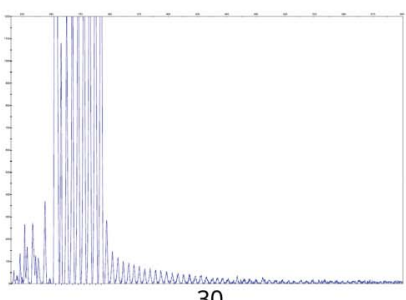

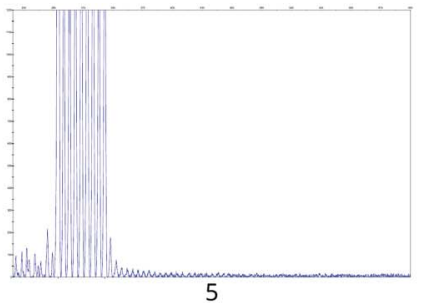

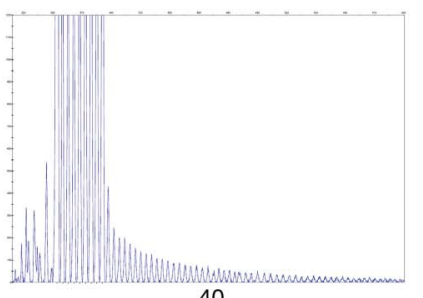

40

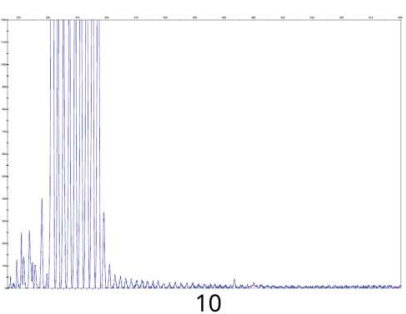

10

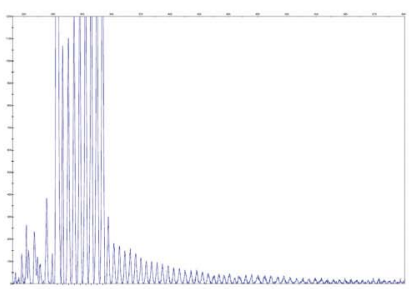

50
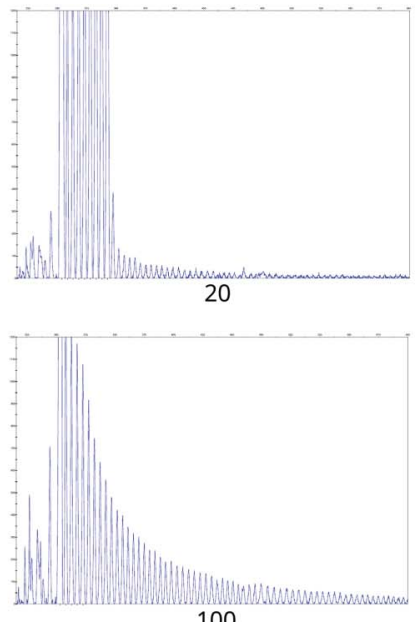

100

Genomic DNA from an individual with germline C9orf72 HRE was diluted in genomic DNA from an individual without germline C9orf72 HRE at various percentages. $\mathrm{HRE}=$ hexanucleotide repeat expansion; RPPCR = repeat-primed PCR.

\section{Methods}

\section{Samples}

The spinal cords from 19 ALS cases were included in this study. DNA obtained from prior blood samplings of these cases established them all to be negative for the C9orf72 HRE. Samples were collected from 3 institutions: the Montreal Neurological Institute and Hospital in Montréal, Québec; the Sunnybrook Health Sciences Centre in Toronto, Ontario; and the ALS Clinic at the London Health Science Centre in London, Ontario. Average patient age at donation was 65.9 years, with a male-to-female ratio of 1.29. A targeted sequencing approach ${ }^{7}$ was used to test for rare (minor allele frequency < 0.001 ) proteinaltering germline mutations in genes known to be ALS risk factors. Information regarding the ALS cases is listed in table.

\section{Standard protocol approvals, registrations, and patient consents}

All participants signed an informed consent form that was approved by the ethical review boards of institutions that contributed the material.

\section{Tissue sectioning and DNA extraction}

Spinal cords were manually portioned into transverse sections of approximately $5 \mathrm{~mm}$ thickness. Sections were then separated along the coronal plane into dorsal and ventral halves, with only the ventral areas being used in the present study. Each ventral portion was separated into left and right ventral horns. Genomic DNA was extracted using standard salting-out methods from approximately half of both the left and right ventral portions of every section available from each spinal cord.

\section{C9orf72 HRE reactions}

C9orf72 HRE genotyping ${ }^{8}$ was performed on blood DNA samples (or sampling of the cervical area of the cerebellum if blood was not available) to accurately size germline hexanucleotide repeat alleles. Repeat-primed PCR (RPPCR) ${ }^{9}$ was performed on all sampled sections of each patient to assess for the C9orf72 HRE and to estimate the lengths of C9orf72 alleles in each section. GeneMapper v4.0 (Applied Biosystems) was used to visualize and estimate reaction fragment sizes. Lengths of C9orf72 hexanucleotide repeat amplicons were measured using GeneMapper compared to the GeneScan-500 LIZ Size Standard (Applied Biosystems). Peaks from the RPPCR profiles were chosen based on the genotyping method results to represent C9orf 72 alleles, which were plotted to assess variation within normal-length $C 9$ orf 72 hexanucleotide repeat lengths.

\section{HRE mosaicism index measures}

Genomic DNA from a patient previously established as a C9orf72 HRE carrier was diluted in genomic DNA from an ALS patient without the HRE to generate a percentage of HRE within a sample $(0 \%, 5 \%, 10 \%, 20 \%, 30 \%, 40 \%$, $50 \%$, and $100 \%)$. These dilutions were index measures for the testing of C9orf72 HRE mosaicism within a section; their RPPCR profiles enabled us to assess the sensitivity of the method for each HRE dilution. RPPCR fragment length profiles were visually compared between every spinal cord section and the mosaicism index measures.

\section{Data availability statement}

The authors confirm that the data necessary for confirming the conclusions of this study are available within the article and its supplementary material. Raw data is available upon request.

\section{Results}

\section{Mosaicism detection}

Varying proportions of the C9orf72 HRE diluted in wild-type DNA displayed unique profiles on RPPCR fragment sizing 
(figure 1). We were able to detect as low as $5 \%$ mosaicism based on the profiles generated by our assay.

\section{Spinal sample testing}

A total of 1,053 individual sections were tested by RPPCR in the spinal cords of patients with ALS. No section showed evidence of $C 9$ orf $72 \mathrm{HRE}$ at or above a 5\% mosaicism level in any of the spinal cords tested. All sections from the same spinal cord showed the same profile of RPPCR fragments, and RPPCR peaks (chosen by the amplicon genotyping method sizing) showed that repeat sizing did not significantly change across a spinal cord (figure 2).

\section{Discussion}

Because of the high penetrance of the C9orf72 HRE and the accumulation of repeat RNA fragments and dipeptide proteins, ${ }^{1,9}$ its pathologic mechanism must have a strong (albeit time-dependent) effect. Therefore, there must be a threshold or concentration at which the products and effects of $C 9$ orf $72 \mathrm{HRE}$ are toxic to cells and tissues. It is possible that low levels of C9orf72 HRE not detectable by germline testing could be sufficient to cause disease through accumulation of products.
Our study did not find evidence for C9orf72 HRE somatic expansion in the spinal cords of patients with ALS. This does not preclude the possibility that very low levels of expansion may exist in patients with ALS. However, as we were able to detect the levels of mosaicism at or above 5\%, lowerfrequency somatic mutations would have had to occur late in neural tissue development.

The lengths of C9orf72 hexanucleotide repeats across all sections of the same spinal cord were identical. This result confirms that $C 9$ orf 72 hexanucleotide repeats are stable when in the normal range ${ }^{10}$ and that if instability does occur, it is restricted to expanded alleles. ${ }^{2}$ In C9orf72 expression vectors, the number of hexanucleotide repeats has been reported to contract or expand above a critical number of repeats. ${ }^{4}$ Changes in C9orf 72 hexanucleotide repeat length might occur more readily in artificial systems, and in human neural cells there may be a mechanism to prevent frequent alterations. Very large C9orf 72 HRE can exhibit a range of repeat lengths across tissues of an individual ${ }^{10}$; however, these pathogenic expansions likely occur in most or all cells of an individual and the exact number of repeats triggering the disease remains to be established.

Figure 2 RPPCR fragment sizes in the spinal cord sections of patients with ALS

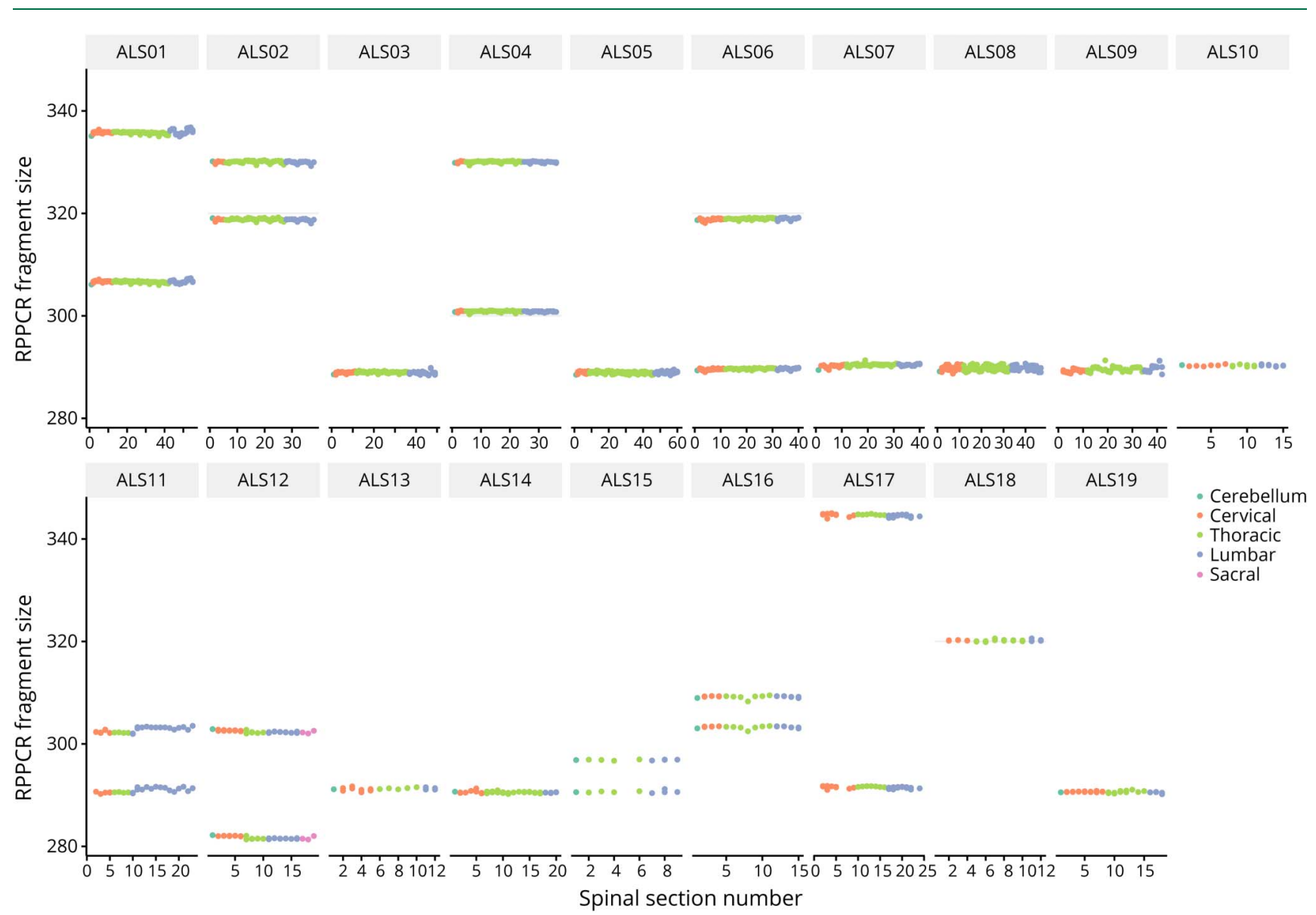

RPPCR peaks representing the measured C9orf72 HRE alleles were chosen based on the results of the amplicon genotyping method. ALS = amyotrophic lateral sclerosis; HRE = hexanucleotide repeat expansion; RPPCR = repeat-primed PCR. 
Our study is limited by sample size, as it is difficult to acquire large numbers of spinal cords from patients with ALS. Based on our results, if somatic expansion occurs at the level detectable by our assays, it is likely that it does not account for a large proportion of ALS cases, not occurring in large clusters of neuronal cells. However, as we sampled exclusively from the ventral spinal cord, our assay did not test for somatic events in dorsal neurons or glial cells, which could be sources of pathogenic protein seeding.

Study of the C9orf 72 HRE remains difficult because of the technological limitations of sequencing GC-rich and repetitive regions of the genome. Techniques such as single cell and long-read sequencing may allow detection of very low-level somatic events and precise measurement of the C9orf72 HRE length.

\section{Acknowledgment}

The authors thank the participants for their contribution to the study. The authors would like to thank Cynthia Bourassa, Fulya Akçimen, Boris Chaumette, Calwing Liao, and Qin He for their assistance in reviewing the manuscript and scientific content. Thanks are also due to Vessela Zaharieva and Cathy Mirarchi for their assistance in clinical coordination. The authors thank the Douglas Bell Canada Brain Bank (McGill University), Sunnybrook Health Sciences Centre (University of Toronto), and the Schulich School of Medicine and Dentistry of Western University for providing the material and relevant clinical information.

\section{Study funding}

Amyotrophic Lateral Sclerosis Society of Canada.

\section{Disclosure}

J.P. Ross has received a doctoral student fellowship from the ALS Society of Canada and a Canadian Institutes of Health Research Frederick Banting \& Charles Best Canada Graduate Scholarship (FRN 159279). C.S. Leblond, H. Catoire, K. Volkening, M. Strong, L. Zinman, J. Robertson, and P.A. Dion reports no disclosures. G. A Rouleau has received support from the Canadian Institute of Health Research (CIHR). Full disclosure form information provided by the authors is available with the full text of this article at Neurology.org/NG.

\section{Publication history}

Received by Neurology: Genetics October 26, 2018. Accepted in final form February 19, 2019.

Appendix Author contributions

\begin{tabular}{|c|c|c|c|}
\hline Name & Location & Role & Contribution \\
\hline Jay P. Ross, BSc & $\begin{array}{l}\text { McGill University, } \\
\text { Montréal, QC, } \\
\text { Canada }\end{array}$ & Author & $\begin{array}{l}\text { Design and concept } \\
\text { of study; } \\
\text { experimental } \\
\text { procedures; analysis } \\
\text { and interpretation of } \\
\text { the data; and drafting } \\
\text { the manuscript for } \\
\text { intellectual content }\end{array}$ \\
\hline
\end{tabular}

Appendix (continued)

\begin{tabular}{|c|c|c|c|}
\hline Name & Location & Role & Contribution \\
\hline $\begin{array}{l}\text { Claire S. } \\
\text { Leblond, PhD }\end{array}$ & $\begin{array}{l}\text { Pasteur Institute, } \\
\text { University Paris } \\
\text { Diderot, Sorbonne } \\
\text { Paris Cité, Paris, } \\
\text { France }\end{array}$ & Author & $\begin{array}{l}\text { Design and concept } \\
\text { of study; } \\
\text { experimental } \\
\text { procedures; } \\
\text { analysis and } \\
\text { interpretation of } \\
\text { the data; and } \\
\text { drafting the } \\
\text { manuscript for } \\
\text { intellectual content }\end{array}$ \\
\hline $\begin{array}{l}\text { Hélène } \\
\text { Catoire, PhD }\end{array}$ & $\begin{array}{l}\text { McGill University, } \\
\text { Montréal, QC, } \\
\text { Canada }\end{array}$ & Author & $\begin{array}{l}\text { Experimental } \\
\text { procedures; and } \\
\text { drafting the } \\
\text { manuscript for } \\
\text { intellectual } \\
\text { content }\end{array}$ \\
\hline $\begin{array}{l}\text { Kathryn } \\
\text { Volkening, PhD }\end{array}$ & $\begin{array}{l}\text { Schulich School of } \\
\text { Medicine and } \\
\text { Dentistry, Western } \\
\text { University, London, } \\
\text { Ontario, Canada. }\end{array}$ & Author & $\begin{array}{l}\text { Experimental } \\
\text { procedures; and } \\
\text { drafting the } \\
\text { manuscript for } \\
\text { intellectual } \\
\text { content }\end{array}$ \\
\hline $\begin{array}{l}\text { Michael } \\
\text { Strong, MD, } \\
\text { FRCPC, FANN, } \\
\text { FCAHS }\end{array}$ & $\begin{array}{l}\text { Schulich School of } \\
\text { Medicine and } \\
\text { Dentistry, Western } \\
\text { University, London, } \\
\text { Ontario, Canada. }\end{array}$ & Author & $\begin{array}{l}\text { Clinical } \\
\text { assessment of } \\
\text { patients; } \\
\text { experimental } \\
\text { procedures; and } \\
\text { drafting the } \\
\text { manuscript for } \\
\text { intellectual } \\
\text { content }\end{array}$ \\
\hline
\end{tabular}

\begin{tabular}{|c|c|c|c|}
\hline $\begin{array}{l}\text { Lorne Zinman, } \\
\text { MD, MSc, } \\
\text { FRCPC }\end{array}$ & $\begin{array}{l}\text { Sunnybrook Health } \\
\text { Sciences Centre, } \\
\text { Toronto, ON, } \\
\text { Canada }\end{array}$ & Author & $\begin{array}{l}\text { Clinical assessment } \\
\text { of patients; and } \\
\text { drafting the } \\
\text { manuscript for } \\
\text { intellectual content }\end{array}$ \\
\hline $\begin{array}{l}\text { Janice } \\
\text { Robertson,PhD }\end{array}$ & $\begin{array}{l}\text { University of } \\
\text { Toronto, Toronto, } \\
\text { ON, Canada }\end{array}$ & Author & $\begin{array}{l}\text { Drafting the } \\
\text { manuscript for } \\
\text { intellectual content }\end{array}$ \\
\hline $\begin{array}{l}\text { Patrick A. } \\
\text { Dion, PhD }\end{array}$ & $\begin{array}{l}\text { McGill University, } \\
\text { Montréal, QC, } \\
\text { Canada }\end{array}$ & Author & $\begin{array}{l}\text { Design and concept } \\
\text { of study; } \\
\text { interpretation of the } \\
\text { data; and drafting or } \\
\text { revising the } \\
\text { manuscript for } \\
\text { intellectual content }\end{array}$ \\
\hline $\begin{array}{l}\text { Guy A. } \\
\text { Rouleau, MD } \\
\text { PhD, FRCPC }\end{array}$ & $\begin{array}{l}\text { McGill University, } \\
\text { Montréal, QC, } \\
\text { Canada }\end{array}$ & Author & $\begin{array}{l}\text { Design and concept } \\
\text { of study; } \\
\text { interpretation of the } \\
\text { data; and drafting or } \\
\text { revising the } \\
\text { manuscript for } \\
\text { intellectual content }\end{array}$ \\
\hline
\end{tabular}

\section{References}

1. Taylor JP, Brown RH Jr, Cleveland DW. Decoding ALS: from genes to mechanism. Nature 2016;539:197-206.

2. Pamphlett R, Cheong PL, Trent RJ, Yu B. Can ALS-associated C9orf72 repeat expansions be diagnosed on a blood DNA test alone? PLoS One 2013;8: e70007.

3. Leija-Salazar M, Piette C, Proukakis C. Review: somatic mutations in neurodegeneration. Neuropathol Appl Neurobiol 2018;44:267-285.

4. Thys RG, Wang YH. DNA replication dynamics of the GGGGCC repeat of the C9orf72 gene. J Biol Chem 2015;290:28953-28962.

5. Westergard T, Jensen BK, Wen X, et al. Cell-to-Cell transmission of dipeptide repeat proteins linked to C9orf72-ALS/FTD. Cell Rep 2016;17:645-652. 
6. Lee MH, Siddoway B, Kaeser GE, et al. Somatic APP gene recombination in Alzheimer's disease and normal neurons. Nature 2018;563:639-645.

7. O'Roak BJ, Vives L, Fu W, et al. Multiplex targeted sequencing identifies recurrently mutated genes in autism spectrum disorders. Science 2012;338:1619-1622.

8.

Renton AE, Majounie E, Waite A, et al. A hexanucleotide repeat expansion in C9ORF72 is the cause of chromosome 9p21-linked ALS-FTD. Neuron 2011;72:257-268.
9. DeJesus-Hernandez M, Mackenzie IR, Boeve BF, et al. Expanded GGGGCC hexanucleotide repeat in noncoding region of C9ORF72 causes chromosome 9p-linked FTD and ALS. Neuron 2011;72:245-256.

10. Nordin A, Akimoto C, Wuolikainen A, et al. Extensive size variability of the GGGGCC expansion in C9orf72 in both neuronal and non-neuronal tissues in 18 patients with ALS or FTD. Hum Mol Genet 2015;24:3133-3142. 


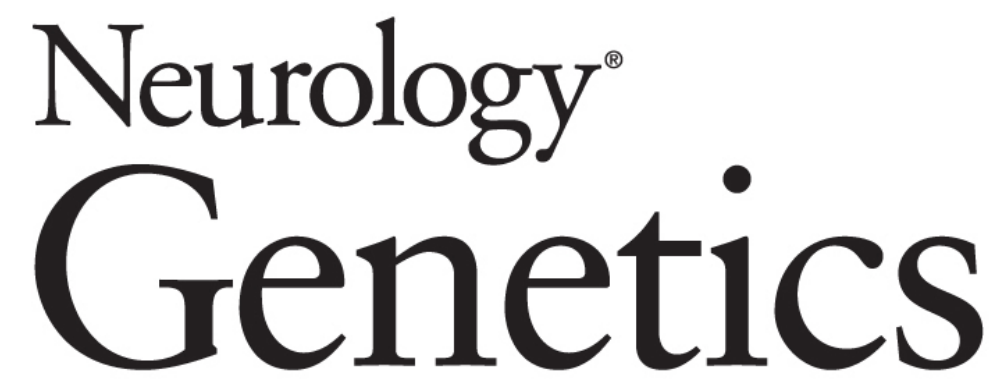

Somatic expansion of the C9orf72 hexanucleotide repeat does not occur in ALS spinal cord tissues

Jay P. Ross, Claire S. Leblond, Hélène Catoire, et al. Neurol Genet 2019;5;

DOI 10.1212/NXG.0000000000000317

This information is current as of March 20, 2019

Neurol Genet is an official journal of the American Academy of Neurology. Published since April 2015, it is an open-access, online-only, continuous publication journal. Copyright Copyright $\odot 2019$ The Author(s). Published by Wolters Kluwer Health, Inc. on behalf of the American Academy of Neurology.. All rights reserved. Online ISSN: 2376-7839.

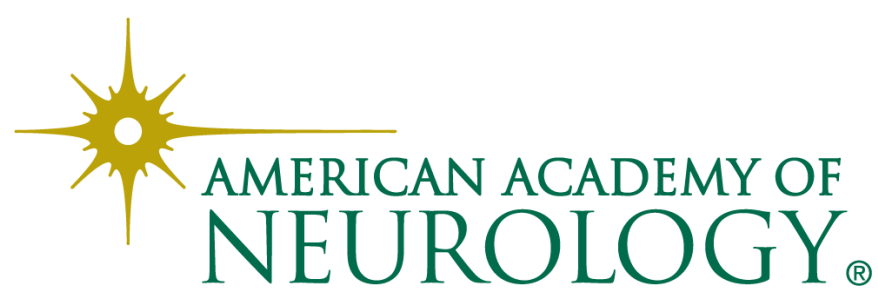




\section{Updated Information \& Services}

References

Citations

Subspecialty Collections

Permissions \& Licensing

Reprints including high resolution figures, can be found at: http://ng.neurology.org/content/5/2/e317.full.html

This article cites 10 articles, 2 of which you can access for free at: http://ng.neurology.org/content/5/2/e317.full.html\#\#ref-list-1

This article has been cited by 3 HighWire-hosted articles: http://ng.neurology.org/content/5/2/e317.full.html\#\#otherarticles

This article, along with others on similar topics, appears in the following collection(s):

\section{All Genetics}

http://ng.neurology.org//cgi/collection/all_genetics All Spinal Cord

http://ng.neurology.org//cgi/collection/all_spinal_cord

Amyotrophic lateral sclerosis

http://ng.neurology.org//cgi/collection/amyotrophic_lateral_sclerosis_

Information about reproducing this article in parts (figures,tables) or in its entirety can be found online at:

http://ng.neurology.org/misc/about.xhtml\#permissions

Information about ordering reprints can be found online:

http://ng.neurology.org/misc/addir.xhtml\#reprintsus

Neurol Genet is an official journal of the American Academy of Neurology. Published since April 2015, it is an open-access, online-only, continuous publication journal. Copyright Copyright $\odot 2019$ The Author(s). Published by Wolters Kluwer Health, Inc. on behalf of the American Academy of Neurology.. All rights reserved. Online ISSN: 2376-7839.

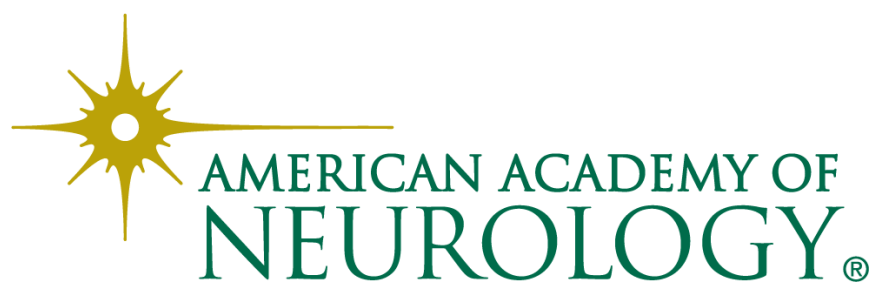

